\author{
Wioleta Wasil
}

\title{
OD BLUŹNIERSTWA DO PRZESTĘPSTWA, CZYLI CO TAK NAPRAWDĘ CHRONI PAŃSTWO: BOGA CZY UCZUCIA RELIGIJNE? STUDIUM HISTORYCZNO-PRAWNE
}

Aktualne brzmienie przepisu dotyczącego przestępstwa obrazy uczuć religijnych skodyfikowane zostało w art. 196 ustawy Kodeks karny ${ }^{1}$. Wykładnia tego artykułu jest powodem wielu problemów interpretacyjnych i funkcjonalnych. Główny spór leży u podstaw genezy tego prawa. Nieporozumienia wynikają przede wszystkim $\mathrm{z}$ faktu utożsamiania przestępstwa obrazy uczuć religijnych z bluźnierstwem, co sprawia, że czyn przestępczy nabiera ściśle religijnego charakteru [Draguła 2013, 171]. Dopiero ustalenie pochodzenia art. 196 k.k. pozwoli na dogłębną analizę zastosowania tej normy.

\section{PRZESTĘPSTWO BLUŹNIERSTWA PRZECIWKO BOGU}

Genezy przestępstwa obrazy uczuć religijnych należy upatrywać w przestępstwie, jakim niegdyś było bluźnierstwo przeciwko Bogu. Obecnie słowa

MGR LIC. Wioleta WASIL - doktorant, Katedra Prawa Konstytucyjnego, Wydział Prawa i Administracji Uniwersytetu Kardynała Stefana Wyszyńskiego w Warszawie; adres do korespondencji: Mirzec Majorat 38, 27-220 Mirzec, Polska; e-mail: wiolawasil@gmail.com; https://orcid.org/0000-0002-6286-1055

${ }^{1}$ Ustawa z dnia 6 czerwca 1997 r. Kodeks karny, Dz. U. z 2018 r., poz. 1600 z późn. zm. [dalej cyt.: k.k.]. 
„bluźnierstwo”oraz „bluźnić”używane są na określenie zachowania, które ma na celu przede wszystkim obrazę Boga, odebranie mu czci lub wyrażenie złości przeciwko Bogu. Bluźnić można nie tylko słowem, jednakże ta forma bluźnierstwa najbardziej zadomowiła się w ludzkiej świadomości. Znanych jest kilka definicji tego słowa, które występuje w węższym znaczeniu bluźnierstwo jako: „urąganie, lżenie, szydzenie skierowane przeciw Bogu albo stworzeniom lub rzeczom - ze względu na Boga, wyrażające się w myśli, słowie lub czynie" [Stachowiak 1967, 669] oraz szerszym znaczeniu (interpretacji), które wykracza poza zakres religijny - bluźnić tzn. „uwłaczać temu, co jest przez kogoś uważane za godne szacunku, co jest ogólnie poważane, cenione, zwłaszcza urągać temu, co jest przez religię uważane za święte”. Bluźnierstwo jako przestępstwo przeciwko Bogu przez wieki figurowało w prawniczych myślach wschodnich i zachodnich cywilizacji. Wpływ chrześcijaństwa na świecką legislację sprawił, że bluźnierstwo stało się przestępstwem państwowym. Kodyfikacja przestępstwa bluźnierstwa miała zapobiec gniewowi Boga. Miała przestrzegać przed występkami przeciwko Bogu i religii, dlatego też, opierając się na Prawie Mojżeszowym, cesarz Justynian Wielki w 538 r. przeprowadził nowelizację prawa i wprowadził kary cielesne za bluźnierstwo, włącznie z karą śmierci. Sankcje wymierzane za nieprzestrzeganie praw miały charakter prewencyjny oraz wynikały ze strachu przed Bogiem. Z noweli cesarza Justyniana jako przedstawiciela rzymskiej myśli prawno-kanonicznej, zaczerpnęły inne ustawodawstwa krajów europejskich. Karol Wielki w 785 r. w Capitulatio de partibus Saxoniae również przewidywał karę śmierci za popełnienie przestępstwa bluźnierstwa przeciwko Bogu, a szczególnie za dokonanie grabieży i wdarcie się do kościoła [Draguła 2013, 172]. Podobne regulacje prawne odnaleźć można w prawodawstwie Fryzów i Wizygotów, w którym to za wdarcie się do kościoła oraz dokonanie grabieży groziła śmierć, np. poprzez grzebanie w mokrym, nadmorskim piasku [Modzelewski 2004, 55-56]. Europejska legislacja okresu średniowiecza aż do XVIII w., a więc do czasów zmiany kierunku myślenia $\mathrm{w}$ stronę oświeconej wizji świata, bardzo restrykcyjnie penalizowała obrazę Boga i Słowa Bożego, aktów oraz przedmiotów kultu. Kara miała przestrzegać przed kolejnym popełnieniem tego przestępstwa, które według ówczesnych prawodawców niosło na ziemię gniew Boży w postaci klęsk żywiołowych, chorób, zaraz czy wojen. Stąd też sankcje za bluźnierstwo były karami cielesnymi, obcinano języki, usta, biczowano, chłostano, wymierzano karę wygnania lub karę śmierci. Bluźnierstwo przeciwko Bogu 
było traktowane jako najcięższe przestępstwo, stąd wymierzane kary były surowe, ciężkie i dotkliwe [Draguła 2013, 171]. Uważano, że przestępca dopuszczający się bluźnierstwa wywołuje nie tylko gniew Boga, ale bezpośrednio uderza w samą osobę króla czy władcy, który na ziemi jest wysłannikiem Boga.

W XV i XVI w. odnotowano największy wzrost procesów za bluźnierstwo. Zauważono pewną tendencję - ilość wydawanych edyktów królewskich dotyczących bluźnierstwa wzrastała wraz z pogarszającą się sytuacją danego państwa. Zdarzały się takie przypadki, jak prześladowania bluźnierców w ramach podziękowania za zwycięstwo, co miało miejsce w 1510 r. po wyprawie Ludwika XII do Włoch, w której odniósł sukces, aczkolwiek należały one do rzadkości. Zazwyczaj klęska, która dotykała kraj, niosła za sobą pasmo procesów o bluźnierstwo.

Wiek XVII utożsamiany jest $\mathrm{w}$ historii z polowaniem na bluźnierców. W okresie tym istniało w Europie wiele ruchów reformacyjnych, które negowały główne prawdy wiary, więc ich nauki traktowane były jako bluźnierstwa heretyckie. Według akt francuskiego trybunału Parlement de Paris w latach 1700-1790 przed sądem za dopuszczenie się przestępstwa bluźnierstwa osądzono 91 osób [tamże, 174]. Wraz z nadejściem XVIII w. zauważyć można znaczący spadek procesów o bluźnierstwo, a ostatnią osobą ukaraną w 1766 r. spaleniem żywcem był kawaler de la Barre, będący znaczącą postacią w historii Francji, w której od momentu śmierci Jeana-François Lefčbvre'a zaprzestano ścigania bluźnierców. Należy jednak zwrócić uwagę na fakt, iż zanim to nastąpiło, bluźnierstwo nie było wyłącznie katolicką domeną. Szwajcarski reformator, Jan Kalwin, również opowiadał się za ochroną religii przez państwo. Daremnie próbował zreformować genewskie ustawodawstwo przeciwko bluźniercom. Uważał, że rolą państwa jest stanie na straży odpowiedniego głoszenia Ewangelii i ochrony kościelnych instytucji. Kalwin nieustępliwie nawoływał do zwalczania heretyków-bluźnierców, którymi według jego nauki byli wszyscy, którzy mieli odmienne poglądy religijne [tamże, 175]. Wizję Kalwina skwapliwie podzielali inni reformatorzy, tacy jak: Marcin Luter, Filip Melanchton oraz Ulrich Zwingli. Na klimat XVIII-wiecznej Europy znaczący wpływ miał rozwój oświecenia, a także doktryna ówczesnych przedstawicieli epoki, która stanowczo odchodziła od kanoniczno-świeckiego charakteru bluźnierstwa, podkreślając państwowe znaczenie tego przestępstwa. Myśl ta spowodowała, że Bóg przestał być podmiotem ochrony prawnej. 
Zmiana kierunku myślenia ewoluowała, nie była to rewolucyjna przemiana. Jeszcze w 1751 r. Kodeks karny bawarski oraz często przywoływana przez historyków Constitutio criminalis theresiana z 1768 r. przewidywały karę śmierci poprzez spalenie na stosie za najcięższe bluźnierstwa [Okrzesik 1995, 672]. Dopiero Kodeks karny z 1787 r., wprowadzony przez cesarza Józefa II, będący jednym z pierwszych owoców oświeconej myśli, odszedł od srogiego karania bluźniercy i zarządził umiejscowienie ich w zakładzie psychiatrycznym, ponieważ ich zachowanie świadczyło o utracie zmysłów [Tazbir 2011, 7].

Analizując bogatą w bluźniercze doświadczenia sytuację Europy, szczególną uwagę należy zwrócić na Polskę, nader tolerancyjne, jak na średniowieczne czasy, państwo. W Polsce od wieków wyznaniem, które gromadziło największą rzeszę wyznawców, był katolicyzm w obrządku zachodnim. Nie można jednak zapominać o protestantach, prawosławnych, Żydach, Tatarach, Cyganach i wielu wiernych innych wyznań. Mimo wzajemnego szacunku do wyznawanych religii i tu spotkać się można $\mathrm{z}$ wpływem krajów europejskich, które masowo walczyły z bluźniercami. Również w Polsce za przestępstwo bluźnierstwa przeciwko Bogu przewidywano karę śmierci. Aby zobrazować, jak ustawodawstwo polskie chroniło Boga, miejsca oraz przedmioty kultu, należy posłużyć się przykładami polskich świętokradców, wśród których najliczniejszą grupę stanowili polscy szlachcice. W 1588 r. na krakowskim rynku spalono Zakrzewskiego, który dopuścił się bluźnierstwa podczas Mszy świętej, raniąc szablą księdza oraz niszcząc hostię i kielich, w 1633 r. szlachcic Bogdaszewski został skazany na ścięcie za porąbanie obrazu Matki Bożej, w 1785 r. inny szlachcic, H. Niemirycz, dopuścił się profanacji hostii, jednak za swoje przewinienia nie został ukarany. Wspomnieć należy także o bluźniercach $\mathrm{z}$ ariańskiej Akademii Rakowskiej, którą po incydencie profanacji krzyża nakazano zamknąć oraz zabroniono jej odbudowy, a wykładowców skazano na banicję [Draguła 2013, 177-78]. Są to pojedyncze przykłady przestępców skazywanych za bluźnierstwo. J. Tazbir zwraca szczególną uwagę na zupełnie inne niż w zachodniej Europie proporcje: „Na tle ogólnej tolerancji i przy braku krwawych prześladowań za wiarę, tym silniej i głośniej wybijały się pojedyncze przypadki. Gdy w innych krajach Europy ofiary tych represji liczono na setki czy nawet tysiące, w Polsce można mówić jedynie o jednostkach" [Tazbir 2011, 15].

Wiek XIX stanowi symbol upadku Państwa Polskiego spowodowanego zaborami, które doprowadziły do rozdziału terytorium państwa, a także 
do zmian kodyfikacji prawa. W zaborze pruskim figurował Kodeks karny z 1871 r., który regulował przestępstwo obrazy uczuć religijnych wierzących. W zaborze austriackim należało przestrzegać Kodeksu karnego z 1851 r., który traktował jeszcze o samoistnym przestępstwie bluźnierstwa przeciwko Bogu. Natomiast przestępstwa przeciwko Bogu w zaborze rosyjskim regulował Kodeks kar głównych i poprawczych z 1847 r. Natomiast w Kodeksie karzqcym Królestwa Polskiego z 1818 r. za bluźnierstwo karano umieszczeniem w więzieniu na okres od 3 do 10 lat [Okrzesik 1995, 672-73].

Na przykładzie Kodeksu karzq̨ego Królestwa Polskiego, poszerzającego katalog sankcji o kary wolnościowe, zauważyć można pewien wyłom w aspekcie przestępstwa bluźnierstwa przeciwko Bogu. Z nadejściem XIX w. zaczęto odchodzić od teologicznego pojmowania bluźnierstwa. Przestępstwo bluźnierstwa przeciwko Bogu zaczęto określać w kodeksach karnych jako obrazę czci religijnej wspólnoty albo obrazę religijną ludzi wierzących. Przestępstwo bluźnierstwa nie występuje już jako samoistny występek. Karalność stała się zależna od dwóch aspektów, to jest skandalu spowodowanego obrazą podmiotu lub przedmiotu czci religijnej danej społeczności oraz formy, jaką ta obraza przybrała. Gruntowna zmiana nastąpiła także w sankcjonowaniu bezprawnych zachowań poprzez włączenie kary pozbawienia wolności oraz obowiązek zadośćuczynienia znieważonej społeczności [Draguła 2013, 182]. Wiek XIX dał podwaliny liberalizacji kar wymierzanych bluźniercom w XX w., kiedy to ostatecznie zniesiono przestępstwo bluźnierstwa przeciwko Bogu w świetle polskiego prawa państwowego.

\section{PRZESTEPSTWA PRZECIWKO \\ WOLNOŚCI SUMIENIA I WYZNANIA \\ W KODEKSIE KARNYM Z 1932 ROKU}

Przegląd penalizacji przestępstwa bluźnierstwa przeciwko Bogu zobrazował wyraźną zmianę w sposobie postrzegania tego czynu zabronionego. Kodeksy państw europejskich zmieniły podmiot ochrony z Boga na prawa wspólnoty ludzi wierzących, którzy są obywatelami danego państwa. Nowe tendencje zostały przeniesione także na polski grunt, dlatego też w pierwszym pozaborowym kodeksie karnym, regulującym przedmiot niniejszych rozważań, ochronie zaczęły podlegać uczucia religijne [Ozdarska 2013, 123]. 
Ustawodawca II Rzeczypospolitej, mając na uwadze, zagwarantowaną w Konstytucji marcowej z 1921 r. ${ }^{2}$, swobodę wyznań, przyjął, że państwo powinno chronić uczucia religijne obywateli. Dlatego też Kodeks karny z 1932 r. $^{3}$ przewidywał trzy rodzaje przestępstw uderzających w uczucia religijne, zawarte w rozdziale XXVI, który nosił nazwę „Przestępstwa przeciwko uczuciom religijnym". Nie można jednak mówić o swobodzie religijnej zagwarantowanej każdej jednostce, ponieważ w przytaczanym rozdziale przyjmowano, iż przedmiotem ochrony są uczucia religijne ogółu społeczeństwa, w przeciwieństwie do ochrony wolności wyznawania dowolnej religii przez jednostkę, a więc każdego obywatela $\mathrm{z}$ osobna. Zabieg był następstwem pewnej zasady, którą odnaleźć można nie tylko w polskim systemie państwowym, to znaczy: „Stanowisko, jakie zajmuje dane ustawodawstwo wobec przestępstw, które najogólniej nazwać by można religijnymi, zależy w dużym stopniu od stanowiska zasadniczego, jakie zajmuje dane społeczeństwo w stosunku do religii (....)" [Warylewski 2005, 367-83]. Stanowisko Państwa Polskiego wyraża w art. 114 Konstytucja marcowa z 1921 r., według której ze względu na dużą ilość wiernych wyznanie rzymskokatolickie zajmuje naczelne stanowisko w państwie spośród równouprawnionych wyznań [Draguła 2013, 184]. Przytoczona argumentacja tłumaczy przedmiot ochrony zagwarantowanej w rozdziale XXVI Kodeksu karnego z 1932 r. Nie odstąpiono jednak zupełnie od przestępstwa bluźnierstwa - art. 172 brzmiał: „Kto publicznie Bogu bluźni podlega karze pozbawienia wolności do lat 5”. Przepis ten był pierwszym z wymienionych w rozdziale XXVI oraz najpoważniejszym przestępstwem religijnym w Kodeksie karnym z 1932 r. Zakres podmiotowy tego przestępstwa, choć bezpośrednio wskazuje na Boga, obejmował uczucia religijne wierzących, ponieważ przez poniżenie Boga następuje obraza całej religii [Wróblewski 1938, 92]. Kodeks karny z 1932 r. w art. 172 traktuje o Bogu w ujęciu monoteistycznym ,jako Najwyższej Istocie pojętej abstrakcyjnie, ale osobowo (...) jak również w rozumieniu pewnej prawnie uznanej religii, np. Jehowa (Jahve), Allah, Trójca święta itp." [Makarewicz 1932, 270]. Zakres przedmiotowy natomiast polegał na bluźnieniu przeciwko Bogu, co utożsamiane było z zachowaniem naruszającym cześć i dobre imię Boga. Bluźnierstwo mogło być wyrażone

${ }^{2}$ Ustawa z dnia 17 marca 1921 r. Konstytucja Rzeczypospolitej Polskiej, Dz. U. Nr 44, poz. 267.

${ }^{3}$ Rozporządzenie Prezydenta Rzeczypospolitej z dnia 11 lipca 1932 r. Kodeks karny, Dz. U. Nr 60, poz. 571. 
wprost poprzez obelżywe czyny, słowa, jak i symbolicznie poprzez obraźliwe gesty [Peiper 1933, 169]. Przestępca łamał prawo wtedy, kiedy bluźnił w miejscach publicznych, w których mógł obrazić uczucia innych, aczkolwiek w wykładni przepisu brak wymogu o wywołaniu publicznego zgorszenia. Zgorszenie jest pojęciem względnym i podlega subiektywnej ocenie. Przestępstwo z art. 172 Kodeksu karnego z 1932 r., choć dokonane publicznie, lecz bez bezpośredniego zamiaru zranienia uczuć religijnych, bądź bluźnierstwo niewymierzone bezpośrednio w kierunku Boga, nie wyczerpuje wszystkich znamion czynu zabronionego, gdyż istotna jest bezpośredniość zachowania [Migros 1982, 199].

Rozdział XXVI Kodeksu karnego z 1932 r. przewidywał także przestępstwo obrazy religii, sankcjonując je w art. 173: „Kto publicznie lży lub wyszydza uznane prawnie wyznanie lub związek religijny, jego dogmaty, wierzenie lub obrzędy, albo znieważa przedmiot jego czci religijnej lub miejsce przeznaczone do wykonywania jego obrzędów religijnych, podlega karze więzienia do lat 3". Zakres przedmiotowy tego przestępstwa dotyczył wyszydzania wyznań i dogmatów religijnych, a także znieważenia miejsc i przedmiotów kultu. Zachowanie wypełniało znamiona czynu zabronionego w momencie, w którym kierowane było do wyznań i związków wyznaniowych uznanych w prawnym systemie państwa [Makarska 2005, 53]. Doktryna za przedmioty kultu uznawała np. hostię, szkaplerz, różaniec, figury świętych itd., natomiast miejscem przeznaczonym do sprawowania obrzędów nie były tylko kościół czy kaplica, lecz także inne miejsca, w których w danym momencie odbywały się nabożeństwa, np. droga podczas procesji Bożego Ciała [Makarewicz 1932, 271].

Przedstawione artykuły sankcjonujące przestępstwa religijne zawarte w rozdziale XXVI Kodeksu karnego z 1932 r. były owocem zmian ustrojowych państwa.

\section{PRZESTĘPSTWA PRZECIWKO WOLNOŚCI SUMIENIA I WYZNANIA W KODEKSIE KARNYM Z 1949 ROKU}

Po zakończeniu II wojny światowej Polska na mocy ustaleń w Jałcie została przyłączona do bloku państw komunistycznych. System totalitarny, który panował w tych państwach, narzucał społeczeństwu materialistyczny 
światopogląd. Tu również miała zastosowanie ogólna reguła mówiąca o tym, że zakres ochrony karnej przestępstw religijnych zależy od stanowiska, jakie państwo zajmuje wobec religii. Władze totalitarne były wrogo nastawione do Kościoła katolickiego i wierzących obywateli państwa. Kodyfikację ochrony wolności sumienia i wyznania wykorzystywano jako narzędzie do walki z religią, a szczególnie z Kościołem katolickim [Makarska 2005, 54]. Mimo iż władze komunistyczne hołdowały egalitarnemu charakterowi ustroju państwa, w rzeczywistości dyskryminowano wierzących, wprowadzając naczelne zasady marksizmu. Przewidziana w Kodeksie karnym z 1932 r. ochrona uczuć religijnych nie była zagwarantowana w powojennej Polsce. Władza Polski Ludowej odbiegała od demokratycznych założeń Kodeksu karnego z 1932 r., wprowadzając pod pozorem ochrony wolności sumienia i wyznania nowe akty normatywne, których sucha litera prawa jakkolwiek odpowiadała ogólnemu dobru obywateli, ale w wykładni przepisów posługiwano się poglądem doktryny i jednolitej linii orzeczniczej, która odbiegała od wolnościowych idei wyznaniowych, wspierając nurt ateistyczny [tamże, 149]. Przy wprowadzeniu swojej ideologii władze komunistyczne posłużyły się dekretem z 22 stycznia 1946 r. o odpowiedzialności za klęskę wrześniowa $i$ faszyzacje życia $w$ kraju 4 oraz dekretem z 13 czerwca 1946 r. o przestępstwach szczególnie niebezpiecznych $w$ okresie odbudowy państwa, tzw. małym kodeksem karnym ${ }^{5}$. Kodyfikacji przestępstw w małym kodeksie przyświecał represyjny cel. Główne założenia polegały na walce $\mathrm{z}$ antysemityzmem, faszyzmem, nienawiścią oraz dyskryminacją narodowościową i wyznaniową, a także na wychowaniu wszystkich obywateli, bez względu na różnice, w duchu współżycia dla dobra państwa [Siewierski 1947, 75-76, 7980]. Nieostry klimat małego kodeksu spowodował jego bardzo luźną, niczym niekontrolowaną interpretację, wedle której nie szanowano różnic, szczególnie tych na tle religijnym, i wprowadzono despotyczną i niesprawiedliwą równość charakterystyczną dla komunistycznego systemu [Makarska 2005, 150]. Kościół katolicki w obliczu areligijnej propagandy komunistycznej wydał 1 lipca 1949 r. dekret św. Oficjum, w którym tłumaczył pewne wątpliwości zawarte w Kodeksie Prawa Kanonicznego z 1917 r. ${ }^{6}$ Dekret ten

\footnotetext{
${ }^{4}$ Dekret z dnia 22 stycznia 1946 r. o odpowiedzialności za klęskę wrześniowa $i$ faszyzację życia państwowego, Dz. U. Nr 5, poz. 46.

${ }^{5}$ Dekret z dnia 13 czerwca 1946 r. o przestępstwach szczególnie niebezpiecznych w okresie odbudowy Państwa, Dz. U. Nr 30, poz. 192.

${ }^{6}$ Codex Iuris Canonici Pii X Pontificis Maximi iussu digestus Benedicti Papae XV auctoritate promulgatus (27.05.1917), AAS 9 (1917), pars II, s. 1-593.
} 
głosił, że wierni nie mogą ani popierać partii komunistycznej, ani należeć do niej, a także propagować i czytać jej publikacji. Powinni chronić się przed wpływem reżimu komunistycznego i nie poddawać się naciskom władz. Według wykładni św. Oficjum zwolennikom ustroju komunistycznego groziła ekskomunika [Wąsek 1995, 27-28; Ziemba 1997, 281]. W odpowiedzi na dekret Kościoła katolickiego władze komunistyczne 5 sierpnia 1949 r. ogłosiły dekret o ochronie wolności sumienia $i$ wyznania ${ }^{7}$, będący narzędziem w rękach władz komunistycznych, wprowadzającym zmiany polityki wyznaniowej Polski Ludowej. Dekret uchylał przepisy XXVI rozdziału Kodeksu karnego z 1932 r. oraz art. 30-4 małego kodeksu karnego [Makarska 2005, 56]. Akt normatywny kodyfikował nowe przestępstwa na tle religijnym, które penalizowano surowymi wymiarami kar, takich jak: pozbawienie wolności na nie mniej niż 3 lata, dożywocie, a w niektórych przypadkach przewidywano również karę śmierci. Posiłkując się katalogiem sankcji, można stwierdzić represyjny charakter dekretu [tamże]. Mimo iż nowym przestępstwom przyświecał szczytny cel ochrony wolności sumienia i wyznania, a także zabezpieczenie przed ograniczeniem praw obywatelskich ze względu na różnice etniczne bądź wyznaniowe, w rzeczywistości nowatorskie artykuły dekretu skutecznie ograniczały prawa i wolności polityczne i społeczne wierzących [Wąsek 1995, 27-28]. W kontekście genezy art. 196 Kodeksu karnego z 1997 r. znaczącym był art. 5 dekretu z 1949 r., w którym komunistyczny ustawodawca uregulował przestępstwo obrazy uczuć religijnych w sposób następujący: „Kto obraża uczucia religijne, znieważając publicznie przedmiot czci religijnej lub miejsce przeznaczone do wykonywania obrzędów religijnych, podlega karze więzienia do lat 5”. Innowacyjność tego przepisu polegała na tym, że jako pierwszy akt normatywny w Polsce wprost traktował o uczuciach religijnych. W odróżnieniu od Kodeksu karnego z 1932 r., który - jakkolwiek ustanowił uczucia religijne przedmiotem ochrony $\mathrm{w}$ rozdziale XXVI - w rzeczywistości karał za popełnienie przestępstw, takich jak znieważenie przedmiotu czci religijnej bądź miejsca przeznaczonego do wykonywania obrzędów religijnych. Dekret z 1949 r. prezentuje odmienną sytuację - w art. 5 to uczucia religijne są głównym przedmiotem ochrony, a przedmioty czci religijnej lub miejsca przeznaczone do wykonywania kultu zostały jedynie z nimi związane.

Przestępstwo obrazy uczuć religijnych przybierało różne formy - można było dopuścić się go tak samo słowem, jak i czynem [Makarska 2005, 151].

${ }^{7}$ Dekret z dnia 5 sierpnia 1949 r. o ochronie wolności sumienia i wyznania, Dz. U. Nr 45, poz. 334. 
Według orzecznictwa Sądu Najwyższego Polski Ludowej, aby popełnić przestępstwo z art. 5 dekretu z 1949 r. wystarczyło wyłącznie znieważyć przedmiot kultu, nie dopuszczając się jego zniszczenia, a samo przestępstwo miało miejsce, gdy dopuszczono się go publicznie, a więc w taki sposób, że skutek przestępstwa dotknął bliżej nieokreśloną liczbę jednostek [Bafia, Hochberg, i Siewierski 1965, 147]. Rzeczywistość jednak nie była zgodna z prawami zagwarantowanymi w dekrecie. Władze Polski Ludowej niszczyły wszelkie przejawy oporu stawiane systemowi komunistycznemu. Opierając się na konstytucyjnej zasadzie rozłamu państwa od Kościoła wynikającej z Konstytucji z 1952 r., rząd PRL dekonstruował dotychczasowe relacje państwo - Kościół. Ocenzurowano wydawnictwa kościelne, inwigilowano klasztory i seminaria duchowe, lekcje religii ze szkół publicznych przeniesiono do salek katechetycznych, wprowadzono totalne zeświecczenie państwa [Makarska 2005, 152].

Wobec powyższego, należy stwierdzić, że polityka karno-wyznaniowa Polski Ludowej ograniczała wolność sumienia i wyznania, a w niektórych momentach jej pozbawiała, nie chroniła uczuć religijnych obywateli, chyba że stanowili oni niewierzącą część społeczeństwa [Krukowski 1999, 13].

\section{PRZESTĘPSTWA PRZECIWKO WOLNOŚCI SUMIENIA I WYZNANIA W KODEKSIE KARNYM Z 1969 ROKU}

W bezlitosnym dekrecie o ochronie wolności sumienia i wyznania, hołdującym relacji ŕ rebours państwa i Kościoła, od 1956 r. zaczęto zauważać pewne zmiany zmierzające $\mathrm{w}$ kierunku łagodzenia stosowanej polityki. Niniejszy akt normatywny stopniowo gubił przymioty okrucieństwa [Wąsek 2000, 251-52]. Kres jego obowiązywaniu przyniósł rok 1969 - ustawa z 19 kwietnia, tj. przepisy wprowadzające kodeks karny ${ }^{8}$, uchyliła część przepisów dekretu z 1949 r. Nowy kodeks karny wszedł w życie 1 stycznia 1970 r., stanowiąc "ewolucyjną ciągłośćc dotychczas obowiązujących przepisów dekretu z 1949 r. [Makarska 2005, 152]. Kodeks, odpowiadając duchowi czasów, prezentował najważniejsze założenia doktryny socjalistycznej oraz realizował założenia władz komunistycznych [Jermak 1970, 313-19]. Swobodę sumienia, wyznania i religii zagwarantowaną w Kodeksie karnym z 1969 r., ograniczała zasada działania w granicach prawa, co oznaczało, iż

\footnotetext{
${ }^{8}$ Ustawa z dnia 19 kwietnia 1969 r. Kodeks karny, Dz. U. Nr 133, poz. 94.
} 
dana swoboda nie może pozostawać w opozycji do innych interesów Polski Ludowej [Grzelak 1979, 44-45]. Ustawodawca kodeksowy zakreślił wyraźną granicę, gdzie zaczynała i kończyła się wolność obywatela. Granicą tą była wolność drugiego człowieka, poszanowanie, zachowanie ładu i porządku prawnego państwa komunistycznego. Na podstawie powyższego opisu nasuwa się bezsprzeczny wniosek, iż ustawodawca komunistyczny pod zasłoną równouprawnienia obywateli będących wyznawcami różnych religii „zapewniał szczególną ochronę bezwyznaniowości” [Makarska 2005, 58]. Kodeks karny z 1969 r. gwarantował ochronę wolności sumienia i wyznania w przepisach ulokowanych w rozdziale XXVIII zatytułowanym „Przestępstwa przeciwko wolności sumienia i wyznania”. Katalog przestępstw na tle wyznaniowym mocno nawiązywał do dekretu z 1949 r., aczkolwiek cechował się łagodniejszym wymiarem kar w porównaniu ze stanem prawnym z 1949 r., nie pozbywając się tym samym represyjnego charakteru. Nowatorskim ujęciem były przestępstwa wprost wskazujące na gorsze traktowanie wyznawców Boga, stawiając w lepszej sytuacji ateistów. W rozdziale XXVIII Kodeksu karnego z 1969 r. uregulowano dziewięć przestępstw, których penalizacja miała zagwarantować prawnokarną ochronę wolności sumienia i wyznania. Jednym z nich był prekursorski dla art. 196 k.k. przepis regulujący obrazę uczuć religijnych wyrażony w art. 198 Kodeksu karnego z 1969 r. Wiernie oddawał postanowienia art. 5 dekretu o ochronie wolności sumienia i wyznania, zawężając ostrość wykładni - art. $198 \mathrm{Ko}$ deksu karnego z 1969 r. brzmiał: „Kto obraża uczucia religijne innych osób, znieważając publicznie przedmiot czci religijnej lub miejsce przeznaczone do publicznego wykonywania obrzędów religijnych, podlega karze pozbawienia wolności do lat 2, ograniczenia wolności albo grzywny" [tamże, 152]. Kodeks karny z 1969 r. załagodził wymiar kary za popełnienie przestępstwa bluźnierstwa w porównaniu do art. 5 dekretu z 1949 r., doprecyzował pojęcie uczuć religijnych o uczucia „innych osób”, a także wymagał, aby miejsce przeznaczone było do publicznego wykonywania obrzędów religijnych [Ozdarska 2013, 124]. Elementem przestępstwa z art. 198 była obraza uczuć religijnych innych osób, co oznaczało, iż obrażanie przedmiotu czci bądź miejsca kultu osób, religii bądź wyznania, które w Polsce nie występuje, nie wyczerpywało znamion tego czynu. Wykładnia art. 198 Kodeksu karnego z 1969 r., wskazuje: jeśli przedmioty czci budziły wątpliwości bądź istniały co do nich odmienne poglądy różnych Kościołów, nie były uznawane za przedmiot ochrony art. 198 [Popławski 1978, 339]. To od jednoznaczności opinii wyznawców danej religii zależało, co władze państwowe uznawały za przed- 
miot czci religijnej. Popełnienie przestępstwa mogło przybierać różne formy, takie jak: rozpowszechnianie treści obrażających uczucia religijne innych, wypowiadanie obraźliwych słów, niszczenie przedmiotu czci lub miejsca kultu oraz wiele innych. Uczucia, o których traktuje się, powinny być odzwierciedleniem wewnętrznego stanu jednostki oraz jej relacji z otoczeniem [Makarska 2005, 154]. Należy podkreślić, iż znamion przestępstwa z art. 198 Kodeksu karnego z 1969 r. nie wyczerpywała krytyka danej religii, jej dogmatów, prawd wiary, podstawowych założeń, poglądów przedstawianych przez duchownych. Obrazą nie było także usuwanie krzyży, obrazów bądź innych emblematów religijnych, np. ze szkół, urzędów lub innych instytucji pożytku społecznego i publicznego. Sąd Najwyższy w jednym ze swoich orzeczeń orzekł, iż usuwanie znaków i symboli religijnych oddaje ideę rozdziału Kościoła od państwa zagwarantowaną w Konstytucji z 1952 r., ponadto usuwający je nie działa w zamiarze bezpośrednim obrazy uczuć religijnych innych osób, zatem nie można potraktować tego jako przestępstwa z art. 198 Kodeksu karnego z 1969 r. [Bafia, Mioduski, i Siewierski 1987, 208]. Interpretacja przepisu wskazuje na celowość działania sprawcy, który chciał obrazić uczucia religijne innych osób lub godził się na to. Art. 198 traktuje o przestępstwie popełnionym umyślnie w zamiarze bezpośrednim bądź ewentualnym.

Kodeks karny z 1969 r. był kolejnym, zapewnionym przez komunistycznego ustawodawcę, fałszywym gwarantem ochrony wolności sumienia i wyznania każdego obywatela. Martwość stosowania przepisów z rozdziału XXVIII Kodeksu karnego z 1969 r. polegała na tym, iż sucha litera prawa odbiegała od nadinterpretacyjnej wykładni, która w efekcie doprowadzała do licznych prześladowań na tle religijnym i światopoglądowym w czasach Rzeczypospolitej Ludowej.

\section{PRZESTĘPSTWA PRZECIWKO WOLNOŚCI SUMIENIA I WYZNANIA W KODEKSIE KARNYM Z 1997 ROKU}

Reżim totalitarny, wzmożona inwigilacja i oszukańcze stanowisko państwa do obywatela były przyczynkiem do zmian ustrojowych w Polsce. Powstanie „Solidarności” wzbudziło w Polakach chęć zmiany rzeczywistości, która ich otaczała. Nacisk środowisk solidarnościowych spowodował totalną dezaprobatę ówczesnej władzy komunistycznej. Tym samym skłonił do większej wstrzemięźliwości w stosowaniu przepisów regulujących prze- 
stępstwa religijne. Pierwszą owocną próbą negocjowania warunków zmian ustrojowych państwa były obrady okrągłego stołu. Były one zapowiedzią działań zmierzających do normalizacji i stabilizacji stosunków na linii państwo-Kościół. Pierwsze zmiany zostały wprowadzone na mocy ustawy z 17 maja 1989 r. o stosunku państwa do Kościoła katolickiego w Rzeczypospolitej Polskiej 9 . Wejście w życie niniejszej ustawy spowodowało uchylenie art. 194 i 195 Kodeksu karnego z 1969 r. Jednak do czasu obowiązywania Kodeksu w państwie prawa osobiste jednostki, w tym szczególnie, jeśli chodzi o wolność sumienia i wyznania, zajmowały drugie miejsce w hierarchii ochrony państwa, na podium wciąż znajdowała się osłona ustroju komunistycznego, funkcjonariuszy, porządku politycznego, itd. [Grześkowiak 1990, 33]. Gruntownych zmian wymagał obowiązujący Kodeks karny, stąd też w tym celu powołano Komisję Reformy Prawa Karnego, która przygotowała projekt nowego kodeksu karnego. Uchwalono go 6 sierpnia 1997 r., a wszedł w życie 1 września 1998 r. Nowy kodeks oddawał ducha państwa demokratycznego, spełniał standardy praw człowieka, które gwarantowały akty prawa międzynarodowego. Stał się powodem do dumy i symbolem odbudowy demokratycznego państwa prawa, jakim od 1989 r. powoli stawała się Polska. Akt nawiązywał do tradycji międzywojennego prawa karnego oraz gwarantował poczucie bezpieczeństwa i wolności obywateli [Makarska 2005, 156]. Ustawodawca w k.k. w rozdziale XXIV, zatytułowanym „Przestępstwa przeciwko wolności sumienia i wyznania”, zawiera katalog trzech przestępstw na tle wyznaniowym.

Nie ulega wątpliwości, że nowy kodeks czerpał także z dorobku ustawodawcy komunistycznego, aczkolwiek nadawał tym przepisom wymiar aksjologiczny. Ponadto, należy wskazać zmianę w ulokowaniu rozdziału odnoszącego się do przestępstw przeciwko wolności sumienia i wyznania. W Kodeksie karnym z $1969 \mathrm{r}$. był to XXVIII rozdział, w aktualnym kodeksie jest to rozdział XXIV. Zmiana ta odegrała znaczącą rolę, ponieważ dzięki temu przesunięciu nadano przestępstwom na tle religijnym większe znaczenie, jako podstawowemu dobru prawnemu [Fredrich-Michalska i StachurskaMarcińczak 1997, 195]. Katalog przestępstw w rozdziale XXIV k.k. otwiera art. 194, który gwarantuje ochronę praw wynikających z równego traktowania jednostki ze względu na jej przynależność religijną. Drugie przestępstwo uregulowane jest w art. 195, sankcjonującym zachowania polega-

9 Ustawa z dnia 17 maja 1989 r. o stosunku Państwa do Kościoła katolickiego w Rzeczypospolitej Polskiej, Dz. U. z 2018 r., poz. 380 z późn. zm. 
jące na złośliwym przeszkadzaniu wykonywania aktu religijnego danego Kościoła bądź wspólnoty. Ostatni w rozdziale XXIV k.k. jest art. 196. Jest to przepis gwarantujący ochronę uczuć religijnych innych osób, w swej formule mocno zakorzeniony w art. 198 Kodeksu karnego z 1969 r. oraz art. 5 dekretu z 1949 r. Artykuł 196 demokratycznego kodeksu karnego charakteryzuje się mniejszym stopniem represyjności w porównaniu z aktami z 1949 i 1969 r. Ustawodawca kodeksowy, posiłkując się stopniem dolegliwości, wskazał na stosowanie kar od najłagodniejszej do najsurowszej. Ustawodawca w k.k. za przestępstwa z rozdziału XXIV przewidział ten sam rodzaj kar, stawiając na pierwszym miejscu grzywnę, a na kolejnych ograniczenie i pozbawienie wolności [Makarska 2005, 157]. Istotne jest także to, iż przestępstwa na tle religijnym ścigane są z oskarżenia publicznego.

\section{ZAKOŃCZENIE}

Zarys historii pozwala zaobserwować pochodzenie przestępstwa obrazy uczuć religijnych. Stopniowa zmiana przedmiotu ochrony spowodowała odejście od przestępstwa bluźnierstwa przeciwko Bogu we współczesnym ustawodawstwie kodeksowym. Transgresja przestępstwa bluźnierstwa polegała na utracie religijnego charakteru poprzez zmianę przedmiotu ochrony z Boga na uczucia religijne. Dzięki analizie kodeksów karnych z różnych okresów czasowych można zauważyć, jak kształtował się stosunek państwa do Kościoła na przestrzeni lat. Ta fundamentalna zasada legła u podstaw wszystkich aktów normatywnych regulujących przestępstwa na tle wyznaniowym. Celem artykułu było poznanie pochodzenia przestępstwa obrazy uczuć religijnych. Pochodzenie tego czynu leży u podstaw przestępstwa o charakterze religijnym, którego przedmiotem ochrony był Bóg. Wiedza ta jest wyjątkowo ważna i niezwykle przydatna szczególnie w polemikach ze zwolennikami totalnej marginalizacji roli Kościoła bądź innych wspólnot w kraju oraz miłośników światopoglądu ateistycznego. 


\section{PIŚMIENNICTWO}

Bafia, Jerzy, Kryspin Mioduski, i Mieczysław Siewierski. 1987. Kodeks karny komentarz. T. 2. Warszawa: Wydawnictwo Prawnicze.

Bafia, Jerzy, Leo Hochberg, i Mieczysław Siewierski. 1965. Ustawy karne PRL. Warszawa: Wydawnictwo Prawnicze.

Draguła, Andrzej. 2013. Bluźnierstwo. Między grzechem a przestępstwem. Warszawa: Wydawnictwo Więzi.

Grzelak, Edward. 1979. Wolność sumienia i swoboda praktyk religijnych w PRL a ich funkcjonowanie $w$ krajach kapitalistycznych. Warszawa: Wydawnictwo Prawnicze.

Grześkowiak, Alicja. 1990. „Ocena założeń reformy prawa karnego materialnego w świetle standardów praw człowieka." Przeglad Prawa Karnego 4:32-40.

Jermak, Sławomir. 1970. „Wolność sumienia i wyznania w przepisach nowego kodeksu karnego." Stużba Policji Obywatelskiej 3:313-34.

Krukowski, Józef. 1999. „Represyjność prawa polskiego w zastosowaniu do Kościoła katolickiego w latach 1944-1956.” Roczniki Nauk Prawnych 9, nr 2:5-22.

Makarewicz, Juliusz. 1932. Kodeks karny z komentarzem. Lwów: Ossolineum.

Makarska, Małgorzata. 2005. Przestępstwo przeciwko wolności sumienia i wyznania w Kodeksie karnym $z 1997$ roku. Lublin: Towarzystwo Naukowe KUL.

Migros, Zenon. 1982. „Przestępstwa przeciwko uczuciom religijnym w polskim kodeksie karnym z 1932 roku.” Wojskowy Przeglad Prawniczy 37:187-208.

Modzelewski, Karol. 2004. Barbarzyńska Europa. Warszawa: Iskry.

Okrzesik, Adam. 1995. „Bluźnierstwo. W prawie świeckim.” W Encyklopedia Katolicka, t. 2, red. Feliks Gryglewicz, Romuald Łukaszyk, i Zygmunt Sułowski, Lublin: Towarzystwo Naukowe KUL.

Ozdarska, Lidia. 2013. „Przestępstwo obrazy uczuć religijnych w polskim kodeksie karnym.” Studia Prawnoustrojowe 19:123-35.

Peiper, Leon. 1933. Komentarz do Kodeksu karnego. Kraków: Wydawca Leon Frommer.

Popławski, Henryk. 1978. „Przestępstwo przeciwko wolności sumienia i wyznania.” Służba Milicji Obywatelskiej 3:332-45.

Siewierski, Mieczysław. 1947. Mały kodeks karny i postępowanie doraźne. Komentarz. Łódź: Spółdzielnia Wydawnicza Prawo.

Stachowiak, Leon. 1976. „Bluźnierstwo.” W Encyklopedia Katolicka, t. 2, red. Feliks Gryglewicz, Romuald Łukaszyk, i Zygmunt Sułowski, Lublin: Towarzystwo Naukowe KUL.

Szymczak, Mieczysław. 1978. Stownik języka polskiego. T. 1. Warszawa: Wydawnictwo PWN.

Tazbir, Janusz. 2011. „Bluźniercy, którzy uszli karze.” Nauka 1:7-16.

Warylewski, Janusz. 2005. „Pasja czy obraza uczuć religijnych? Spór wokół art. 196 Kodeksu karnego.” W W kręgu teorii i praktyki prawa karnego. Księga poświęcona pamięci Profesora Andrzeja Waska, red. Leszek Leszczyński, Edward Skrętowicz, i Zbigniew Hołda, 367-83. Lublin: Wydawnictwo UMCS.

Wąsek, Andrzej. 1995. „Przestępstwa przeciwko przekonaniom religijnym de lege lata i de lege ferenda." Państwo i Prawo 7:27-41. 
Wąsek, Andrzej. 2000. „Ochrona uczuć religijnych w prawie karnym.” W Prawo wyznaniowe, red. Henryk Misztal, 25-52. Lublin: Towarzystwo Naukowe KUL.

Wróblewski, Bronisław. 1938. Prawo karne - skrypt. Wilno: Skład główny w księgarni Kazimierza Rutkowskiego.

Ziemba, Zdzisław Albin. 1997. Prawo przeciwko społeczeństwu. Warszawa: Instytut Stosowanych Nauk Społecznych UW.

\section{Od bluźnierstwa do przestępstwa, czyli co tak naprawdę chroni państwo: Boga czy uczucia religijne? \\ - studium historyczno-prawne}

\section{Streszczenie}

Przestępstwo obrazy uczuć religijnych sięga swoimi korzeniami przestępstwa bluźnierstwa przeciwko Bogu, wobec tego religijne podłoże tego przepisu jest niezaprzeczalne. Mając powyższe na względzie, należy odrzucić zarzut jakoby przestępstwo to było wyrazem świeckości państwa, a z religią, w szczególności chrześcijańską, nie miało nic wspólnego. Polska nie jest państwem wyznaniowym, aczkolwiek w stosunkach $\mathrm{z}$ religią znajduje się $\mathrm{w}$ relacji separacji skoordynowanej, czego znamienitym przykładem jest umieszczenie art. 196 w Kodeksie karnym.

Słowa kluczowe: przestępstwo; kodeks karny; bluźnierstwo; uczucia religijne

\section{From Blasphemy to Offence, or What does the State Really Protect: God or Religious Feelings? - a Historical and Legal Study}

\section{Su m m a r y}

The offence against religious feelings has its roots in the offence of blasphemy against God, hence the religious ground of that regulation is undeniable. Considering the above, the imputation that the offence in question is an expression of secularity of the state and that it had nothing to do with religion, especially the Christian religion, should be rejected. Poland is not a confessional state, but in relations with religion it is in a relation of coordinated separation, an eminent example of which is including Art. 196 in the Criminal Code.

Key words: offence; Penal Code; blasphemy; religious feelings

Information about Author: WiOLETA WASIL J.C.L. - Ph.D. student, Department of Constitutional Law, Faculty of Law and Administration at the Cardinal Stefan Wyszynski University in Warsaw; Mirzec Majorat 38, 27-220 Mirzec, Poland; e-mail: wiolawasil@gmail.com; https://orcid.org/0000-0002-6286-1055 